\title{
One Possible Life Insurance Market Response to Ageing
}

\section{Gustavo Ferro}

Universidad Argentina de la Empresa (UADE) and CONICET, Lima 717, 1073 Buenos Aires, Argentina. E-mail: gferro@uade.edu.ar

This paper deals with the reaction of the life insurance industry to ageing and the next massive decumulation phase of pension funds worldwide. The industry has a well-established product, which is the annuity, a unique instrument to cope with longevity risk. But annuity markets remain thin. Demand- and supply-side elements of the market are explored and also regulatory issues. Some proposals are made for a more proactive involvement of the industry in the pension business by addressing demand side, supply side and regulatory concerns. The proposal is a Multi-tier Insurance Package, which combines different insurance products in order to cover longevity risk as well as bequest or long-term care motives.

The Geneva Papers (2009) 34, 119-136. doi:10.1057/gpp.2008.46

Keywords: ageing; pensions; insurance; annuity; regulation

\section{Introduction}

The world's population is ageing and also accumulating significant savings for retirement. Different financial institutions are looking for one piece of the retirement market. What role should the insurance industry play? What products can they offer? How could regulation evolve? What can life insurers do to secure their participation in the market? Can we expect a "mega" or "mini" market response to ageing?

It is said in the insurance industry that "insurance is sold, not bought". Nevertheless, sold to whom? The counterparts include the pensioners themselves, regulators, politicians and international organisations. By its very nature, the insurance industry has a relatively low and conservative profile. Is it time to raise it a few inches? Perhaps it is, if the resulting business justifies it.

Pensioners are ageing and becoming financially wealthy. They are demanding more flexible retirement products. Regulators are pressed by consumer's needs in a complex world where products, competitors and markets are increasingly indistinguishable. Politicians are aware that the reform of pensions is called the "third rail" of politics: touch it and you die. International organisations monitoring financial stability complete the landscape.

In our view, there is a myriad of opportunities and serious challenges for the life insurance industry in the ageing process. The industry must provide clients with flexible products, gain and secure the support of regulators, capture the attention and empathy of politicians and supply international organisations with a package they can "sell" to other stakeholders in their search for stabilised finances. 
120

Following this introduction, the following section briefly outlines the ageing phenomenon. In the next section, we identify the main demand-side elements given more available savings - arising from pension funds in their accumulation phase - to buy insurance products in the next decumulation phase. The subsequent section analyses the supply side of the market: what is being sold, by whom, how and why. The next section discusses regulation. In the penultimate section, we outline some proposals and present some simulations. The last section concludes.

This is a policy paper: we review the state-of-the-art and offer some proposals, which are supported by the literature surveyed and by some simulations, whose only purpose is to illustrate the proposals. Some slightly different shapes could have been imagined for the reforms here suggested.

\section{Ageing}

Before 1900, world population growth was slow, its age structure was relatively constant and few people lived beyond 65. From the first half of the 20th century, life expectancy began to increase, although initially no changes in the population structure occurred. The following decades showed a dramatic fall in the fertility rates (which halved) and an ageing process (see Tables 1 and 2).

By mid-2000, the world population had reached 6.1 billion, growing at 1.25 per cent per year. The United Nations projected that the total population would reach 9.3 billion by 2050 , growing at $0.25-0.5$ per cent annually. The global median age is also expected to increase by over 10 years and reach 37 during 2000-2050. ${ }^{1}$

The fertility rate is falling in developed countries because of the combined effects of lower infant mortality rates, the higher participation of women in the labour market, later childbirth and the escalating costs of raising children. Poor countries tend to have higher fertility rates than rich countries because children are considered an investment rather than as requiring investment, as in rich countries.

In the first decades of the 20th century, the decline in mortality rates stemmed mainly from reductions in mortality arising from infectious diseases at younger ages. During the second half of the century, the decline in mortality was due to reductions in deaths resulting from chronic diseases affecting primarily older persons. Past projections have consistently underestimated actual improvements in longevity. Predictions for the next 50 years have incorporated a slower improvement in mortality and life expectancy than in the recent past. They are deterministic with no probabilities attached. $^{2}$

In response to ageing, around two-thirds of pension reforms in Organisation for Economic Co-operation and Development (OECD) countries automatically linked future pensions to changes in life expectancy. Thirteen of thirty OECD countries introduced some automatic connection between pensions and life expectancy in their retirement systems. The countries rest on diverse solutions in the way life-expectancy risk is shared, resulting from the structure of the reforms. Some proposals include

\footnotetext{
${ }^{1}$ Batini et al. (2006).

2 Antolin (2007).
} 
Table 1 Fertility: past, present and future under different scenarios

\begin{tabular}{lcccccc}
\hline Area & \multicolumn{5}{c}{ Total fertility (children per woman) } \\
\cline { 2 - 6 } & 1970-1975 & $2000-2005$ & $\begin{array}{c}2045-2050 \\
\text { (low) }\end{array}$ & $\begin{array}{c}2045-2050 \\
\text { (medium) }\end{array}$ & $\begin{array}{c}2045-2050 \\
\text { (high) }\end{array}$ & $\begin{array}{c}2045-2050 \\
\text { (constant) }\end{array}$ \\
\hline World & 4.49 & 2.65 & 1.56 & 2.05 & 2.53 & 3.50 \\
More developed & 2.12 & 1.56 & 1.34 & 1.84 & 2.34 & 1.67 \\
$\begin{array}{l}\text { regions } \\
\text { Less developed }\end{array}$ & 5.44 & 2.90 & 1.59 & 2.07 & 2.56 & 3.69 \\
$\begin{array}{l}\text { regions } \\
\text { Africa }\end{array}$ & 6.72 & 4.97 & 2.03 & 2.52 & 3.00 & 5.5 \\
$\begin{array}{l}\text { Asia } \\
\text { Europe }\end{array}$ & 5.08 & 2.47 & 1.42 & 1.91 & 2.41 & 2.98 \\
$\begin{array}{l}\text { Latin America and } \\
\text { the Caribbean }\end{array}$ & 2.16 & 1.40 & 1.33 & 1.83 & 2.33 & 1.45 \\
$\begin{array}{l}\text { North America } \\
\text { Oceania }\end{array}$ & 5.05 & 2.55 & 1.36 & 1.86 & 2.36 & 2.69 \\
\hline
\end{tabular}

Source: Jousten (2007) on World Population Prospects: The 2004 Revision Highlights, United Nations 2005.

Table 2 Life expectancy at birth - present and future

\begin{tabular}{lcc}
\hline Area & $2000-2005$ & $2045-2050$ \\
\hline World & 65.4 & 75.1 \\
More developed regions & 75.6 & 82.1 \\
Less developed regions & 63.4 & 74.0 \\
Africa & 49.1 & 65.4 \\
Asia & 67.3 & 77.2 \\
Europe & 73.7 & 80.6 \\
Latin America and the Caribbean & 71.5 & 79.5 \\
North America & 77.6 & 82.7 \\
Oceania & 74.0 & 81.2 \\
\hline
\end{tabular}

Source: Jousten (2007) on World Population Prospects: The 2004 Revision Highlights, United Nations 2005.

defined contribution (DC) schemes, notional accounts - which mimic some of the features of DC systems - adjusted benefit levels with life expectancy and qualifying conditions linked to life expectancies. ${ }^{3}$

\section{Demand side}

The basic demand-side element is the growth in pension savings, which could be potentially invested in life insurance products. Pension funds have a life cycle, which starts with the accumulation of savings and at some moment it enters a decumulation

\footnotetext{
${ }^{3}$ Whitehouse (2007).
} 
phase. The latter is around the corner since the combination of ageing and growth in funds is giving maturity to the pension systems. The forecasts see a peak of aggregate retirement funds in OECD countries owing to workers' saving up to around 2010, followed by decumulation. ${ }^{4}$

Reforms increasingly shift from pay-as-you-go defined benefit (DB) public systems to supplemental or substitute fully funded DC private arrangements. So far, these arrangements have tended to concentrate on the accumulation phase. ${ }^{5}$ Nearly all OECD countries have made major or minor reforms since 1990, when the spending on pensions for the OECD as a whole represented 6.7 per cent of the GDP. ${ }^{6}$ In 11 OECD countries, mandatory private pensions have replaced public pension provision; two countries have added mandatory private pension savings to existing public plans; and many countries have reformed their public pensions, accommodating greater voluntary private savings. Systemic pension reforms have also been implemented in Latin America, Central and Southern Asia, and Central and Eastern Europe.

Savings accumulated in part as a consequence of the pension reforms. In 2006, total OECD-funded pension markets were valued at U.S.\$24.6 trillion (72.5 per cent of the GDP). Pension funds managed 66.1 per cent of these; banks and investment management companies held 17.7 per cent in retirement products; pension insurance contracts accounted for 14.1 per cent (run by insurance companies); and 2.1 per cent were "book reserves". Bonds and stocks remain the two most important asset classes for pension funds. ${ }^{7}$

Another basic fact is that people purchase few annuities. An annuity is a series of payments made at intervals until a particular event happens (such as the death of the holder - Single Life Annuity - or the death of various persons - Joint Life Annuity). It normally involves a single premium per insurer. A Deferred Annuity is postponed until some time after it has been issued. "The purchase of an annuity may be one of the most important financial transactions in the life of an individual". 8 Moreover, annuitization is generally an irreversible decision. The purchase of a life annuity is consistent with the simplest form of a life cycle model of consumption with no bequest motive. But some retirees wish to maintain part of their assets for other uses.

In the United States there has been a rise in the growth of mutual funds, an expansion of self-directed retirement accounts and a decline in life annuitization in retirement, arising from the shift from DB plans to DC plans, few of which even offer annuities as benefit options. Variable annuities have grown in the form of contracts combining equity ownership and an option to annuitize. Insurance companies introduced variable annuities in the mid-1950s to compete with mutual funds. Annuity sales grew faster than net flows into this market as many variable annuity contracts were terminated and their assets were transferred to new annuities. They provide various forms of insurance and the option to convert a life annuity with the payouts indexed to the performance of a diversified investment portfolio. Returns on assets

\footnotetext{
${ }^{4}$ Davis (2002).

${ }^{5}$ Stewart (2007).

${ }^{6}$ OECD (2007a).

${ }^{7}$ OECD (2007b).

${ }^{8}$ An Bord Pinsean (2004).
} 
held in variable annuities are not taxed until the annuitant receives a distribution from the annuity. The funds accumulated in variable annuity accounts are seldom converted to life-contingent annuities at retirement. Moreover, the majority of the individuals covered by variable annuities are still in the accumulation phase. ${ }^{9}$

Participants in DC schemes have to choose how to employ their assets at retirement. Ameriks $^{10}$ uses historical data from a major DC pension provider to assess the decisions of the participants between 1978 and 2001. His results suggest that there is a demand for more flexible and innovative products. He finds that following the introduction of non-annuity income options in 1988, there was a decline in the use of life-contingent immediate annuities. Since the introduction of the new (and more flexible) options, this choice has climbed. Female participants are more likely to choose the single-life annuity option, presumably because of marital status (they are more prone to be widowed because of their higher longevity). Among women, there was an increase in guaranteed period choice. Both men and women choosing a jointlife annuity showed a strong preference for the "Full-to-Survivor" option and guarantee periods. Among single-life annuitants, the great majority opted for a guarantee period. There was a significant increase in the proportion of persons beginning as later annuitants over time ( 65 and older). The average age of participants using the minimum distribution option is almost constant since it is mandated by regulation. As more options with customised features have become available, many participants have used more than one income option, starting with one and following with another: they use temporary mechanisms that do not necessarily involve life contingencies and distribute only the minimum amount necessary to avoid federal tax penalties. $^{11}$

Because of economies of scope and as life annuities and life insurance naturally hedge for one another, a comparative advantage exists for life insurers in this business. An interesting factor is that a life insurance company will not know whether its contracts with a given cohort of retirees are profitable until most have died.

Annuities are seen to be expensive and risky in many respects. In the U.S. market, an annuitant can pay about 8 per cent more for an annuity than she would in the absence of adverse selection ("annuitants live longer"). Gender-based price discrimination implies that women can expect a replacement rate that is lower than that for men. The timing of retirement is a key element in relation to replacement rates. Alier and Vittas ${ }^{12}$ show that the replacement rate for an American fully invested in equities would have been 180 per cent higher if she had retired in 1995 instead of 1999. There is an element of luck in a retirement date being linked to favourable market conditions (and annuity purchase rates). As a result of volatility in interest rates, individuals are exposed to variations in the premiums at the time of retirement. Annuity premiums are, in principle, a function of bond yields and can vary considerably over time. ${ }^{13}$

\footnotetext{
${ }^{9}$ Brown and Poterba (2004).

${ }^{10}$ Ameriks (2003).

11 Ibid.

12 Alier and Vittas (2001).

${ }^{13}$ Mackenzie and Schager (2004).
} 
An alternative to a purchase of an immediate annuity is the "phased withdrawal", which could be determined according to a fixed benefit level (until death or the exhaustion of funds) or using a variable formula (where the withdrawals are linked to life expectancy). Dus et al. ${ }^{14}$ work with German data. They find that delayed annuitization could provide higher expected benefits with lower expected shortfalls at the cost of lower anticipated bequests. There would seem to be great need for models to guide retirees as they examine trade-offs between consumption and the possibility of leaving a bequest. Such trade-offs involve the exchange of some risk for some return. The advantage of a phased withdrawal strategy, which allocates resources across various mutual funds comprising different assets, is liquidity and bequeathing in the event of early death. But, it does not provide the pooling of longevity risk.

Three specific benefit rules of withdrawal are considered in Dus et al.: ${ }^{15}(1)$ the fixed percentage rule, (2) the $1 / T$ rule and (3) the $1 / E(T)$ rule. In the second case, one way is to set $T$ equal to the oldest age assumed in a mortality table; another is to fix it as the retiree's life expectancy at the time of retirement. The third rule takes into consideration the retiree's remaining life expectancy in a dynamic way. It is used in the United States during the decumulation phase of 401(k) plans, where the tax authority seeks to ensure that retirees consume their tax-qualified accounts instead of leaving them as bequests. The results of simulations from Dus et al. (2003) on different paths of phased withdrawal suggest that some retirees might prefer to engage in a mixed strategy: to undertake phased withdrawals during the early period of retirement and later switch to an annuity. It enhances the payout early on - with relatively low risk - and also incorporates the insurance feature later on.

\section{Supply side}

The study of the demand side highlights the need to design and market products with benefit-plus-bequest-plus-risk features. In developed countries, the traditional ways to pay benefits from DC schemes have been either lump sum withdrawals or some form of life annuity. There are also phased withdrawals and phased withdrawals followed by mandatory annuity conversion.

Annuity contracts could be immediate, deferred or delayed, single-life, joint-life, fixed, indexed, variable, temporary and so on. The purchaser could be an individual or a group (such as the trustees of a pension scheme). In the "Non-Profit" or "Fixed" annuity, the future instalments are guaranteed and are not subject to any fluctuations due to investment conditions in the future. A "With-Profit", or "Graded" or "Variable" annuity guarantees a lower minimum payment and is enhanced with bonuses, which reflect investment returns. Bonuses are subject to investment risk. In a "Unit Linked" or "Real Term" annuity, the payments are expressed as an amount of units in a fund, which fluctuate according to the investments made with the fund. The "Indexed Annuity" links the rate of increase to inflation or wages. The price indexation of annuities guarantees some absolute level of consumption available to

\footnotetext{
14 Dus et al. (2003).

${ }^{15}$ Ibid.
} 
retirees, while linking the annuity to wages allows the retiree to capture the productivity gains of the working generation. ${ }^{16}$ Two options can protect surviving dependents: to incorporate a minimum guaranteed period of payment (the overall cost increases with the annuity length) or to set up a "Joint Life Annuity" (its cost depending upon the age and sex of the dependent compared with that of the pensioner). More complex annuities are more expensive. Different products offer particular guarantees: against risks of longevity, investment, interest rate and inflation.

Under European regulations, an annuity is considered life insurance and can only be bought from a life insurance company. In both OECD and middle-income countries, the typical providers of annuities are the insurance companies, but in developed markets the number of insurers interested in selling annuities has fallen. The annuity business can be particularly unprofitable because of low investment returns and increasing longevity, coupled with high reserve requirements. Thus, the size of the immediate annuity market is small with respect to the presumption of most risk-averse individuals. The implicit cost of private annuities has fluctuated over time and providers depending on the individual's perceptions of mortality.

Ameriks ${ }^{17}$ uses data from the Teachers Insurance and Annuity Association-College Retirement Equities Fund (TIAA-CREF), the largest pension provider in the United States. Its assets are accumulated as a part of an employer-sponsored pension arrangement rather than as a supplemental one. TIAA-CREF offers variable annuity payments using a current mortality table, an assumed interest rate of 4 per cent and combinations of a minimum guaranteed amount of income as benchmark values, as well as a variable part. Some non-annuity options were introduced in 1988. They are known as Interest Payment Retirement Option, Minimum Distribution Option and Systematic Withdrawals and Transfers.

In the U.S. market, the funds invested in a variable annuity are held in subaccounts; independent of the insurance company's other assets because such assets are not subject to claims by an insurance company's creditors in the case of insolvency. Income earned on the annuity investments is tax-deferred until the individual begins to withdraw. Some minimum death benefit has to be included in the contract so as to be eligible for favourable tax treatment. The tax deferment known as "1035 Exchanges" generates the majority of sales in the industry: it can be carried out as a direct transfer of accumulated funds from one annuity policy to another without creating a taxable event. $^{18}$

In Germany, "Riester Plans" offer tax incentives to allocate voluntary savings in individual pension accounts, which at the age of retirement allow the individual to withdraw 20 per cent as a lump-sum distribution. The rest of the resources can be invested in an annuity (provided by insurance companies) or a phased withdrawal plan (offered by mutual funds or banks), which must partly revert to an annuity at the age of 85. In the United Kingdom a portion of the accumulated assets can be taken as a lump sum, while until 2006 the rest had to be employed to buy an annuity by the age of 75 .

\footnotetext{
${ }^{16}$ Jousten (2007).

17 Ameriks (2003).

${ }^{18}$ Brown and Poterba (2004).
} 
In Canada retirees must buy an annuity or create a managed withdrawal plan at the age of 69. Instead, the United States has no mandatory annuitization for 401(k) plans upon retirement. Many workers put their funds into an Individual Retirement Account, which they themselves manage. It is subject to the tax laws requiring minimum distributions beginning at age 70.5. ${ }^{19}$

An annuity is good value if the pensioners exceed the average life expectancy. It is not if interest rates grow after the contract and it is probably not if the priority is to secure some of the capital for surviving relatives upon the retirees' death. Instead, the lump sum has several advantages: to start a personal business, to liquidate debts (i.e., mortgages), to leave a bequest, or to cover costly medical and emergency expenses during retirement. In countries where annuitization is mandatory, regulations have been relaxed to take into account the delay of the annuity purchase in a volatile environment. In more volatile places, like Latin America, the programmed withdrawal choice has been included in the reforms. Annuity markets remain underdeveloped in many OECD countries. Developed annuity markets only exist in Australia, Canada, Switzerland, the United Kingdom, the United States, Chile and Singapore.

Insurance companies are increasingly unwilling to offer these products, or to do so at attractive prices and reinsurance companies are unprepared to take on these risks. Problems to price products arise from increasing longevity. Mortality projections do not abound and some countries use foreign mortality tables. Insurers face the risk of mortality rates falling faster than their calculations and reserving provisions. Where the annuitization is not mandatory, the problem of adverse selection complicates their calculations. Annuitants tend to live longer than the population at large. Annuity providers also have trouble matching assets to their liabilities. They face credit risk, liquidity risk, business risk, investment risk and longevity risk. For the latter, public debt and well-rated corporate ones could offer a hedge. Besides, indexed papers are scarce. $^{20}$

A growing body of research has investigated the Money's Worth Ratio (MWR) or the ratio of the present discounted value to actual premium cost. ${ }^{21}$ The ratio $1 / \mathrm{MWR}$ is the load factor for the annuity. The MWR is usually less than one in empirical investigations and it is consistently higher for the annuitant population than for the general population because of adverse selection. The former is true especially for the U.S. and U.K. markets (Table 3).

The MWR calculations assume no trading costs and no indivisibility problems in the relevant financial instruments or fixed commissions. These features possibly underestimate the opportunity costs implicit in the discount rate for a single annuitant. MWR "does not take account of an annuitant's aversion to penury in old age". Panis, ${ }^{22}$ analysing the pre-retirement expectations and post-retirement well-being of Americans, finds that retirees who could finance more of their consumption in retirement with pension annuities were more satisfied, all other factors remaining

\footnotetext{
${ }^{19}$ Dus et al. (2003).

20 Stewart (2007).

${ }^{21}$ Mackenzie (2002).

22 Panis (2003).
} 
Table 3 MWR for a group of countries on nominal annuities (immediate single payment life annuities)

\begin{tabular}{|c|c|c|c|c|c|c|c|c|c|c|}
\hline & \multicolumn{2}{|c|}{ Australia } & \multicolumn{2}{|c|}{ Canada } & \multicolumn{2}{|c|}{ Switzerland } & \multicolumn{2}{|c|}{$U . K}$. & \multicolumn{2}{|c|}{ U.S. } \\
\hline & $\begin{array}{c}\text { General } \\
\text { population }\end{array}$ & $\begin{array}{l}\text { Annuitant } \\
\text { population }\end{array}$ & $\begin{array}{c}\text { General } \\
\text { population }\end{array}$ & $\begin{array}{l}\text { Annuitant } \\
\text { population }\end{array}$ & $\begin{array}{c}\text { General } \\
\text { population }\end{array}$ & $\begin{array}{l}\text { Annuitant } \\
\text { population }\end{array}$ & $\begin{array}{c}\text { General } \\
\text { population }\end{array}$ & $\begin{array}{l}\text { Annuitant } \\
\text { population }\end{array}$ & $\begin{array}{l}\text { General } \\
\text { population }\end{array}$ & $\begin{array}{l}\text { Annuitant } \\
\text { population }\end{array}$ \\
\hline $\begin{array}{l}\text { Male } 65 \text {, using public bond } \\
\text { rate or yield curve }\end{array}$ & 0.914 & 0.986 & 0.925 & 1.014 & 0.965 & 1.169 & 0.897 & 0.966 & 0.816 & 0.916 \\
\hline $\begin{array}{l}\text { Female } 65 \text {, using public } \\
\text { bond rate or yield curve }\end{array}$ & 0.914 & 0.970 & 0.937 & 1.015 & 1.029 & 1.152 & 0.910 & 0.957 & 0.829 & 0.893 \\
\hline $\begin{array}{l}\text { Female } 65 \text {, using corporate } \\
\text { bond rate or yield curve }\end{array}$ & 0.839 & 0.885 & 0.874 & 0.941 & 0.974 & 1.083 & 0.860 & 0.901 & 0.745 & 0.797 \\
\hline
\end{tabular}

$\mathrm{MWR}=C$ /actual premium in the market.

$C=\sum_{i=1}, \ldots, n\left[A d /(1+r)^{i}\right]$,

where $C=$ present value, $A=$ fixed payment, $n=$ maximum number of years an individual survives after purchase of the annuity, $r=$ assumed constant rate of interest, $d=$ probability the individual survives to the $i$ th year after retirement.

Source: Drawn from Mackenzie (2002). 
constant. We study two measures of retirement well-being: self-reported satisfaction with retirement and the self-reported number of depressive symptoms. The guaranteed income benefits may reduce anxiety about the risks of asset depletion by outliving one's savings.

Compulsory annuitization can lead to substantial losses for less risk-averse investors. In a context of non-mandatory annuitization, people could believe it is optimal to invest their retirement assets, making periodical withdrawals. The retiree must select both an investment strategy and a withdrawal rate. Financial advisors often recommend "rules of thumb": $X$ per cent in bonds, $(1-X)$ per cent in stocks and a periodical withdrawal of $w$ per cent per year $(X=0.6$, or $1-X=100-$ age and $w=4$ per cent of initial wealth are commonly advised). But these strategies do not protect against longevity and pose investment risks for the retiree. The possibility of linking the withdrawals to the fund balance each period protects against the risk of running out of money but introduces fluctuations in the income of the retiree. Horneff et al. ${ }^{23}$ show that the appropriate mix depends on the risk aversion of the retiree, as well as assumptions regarding the capital market and actuarial tables. They find the fixed percentage rule is preferred across a wide variety of risk preferences and its preference decreases with risk aversion. Only the very risk-averse will ever find the fixed annuity appealing, ceteris paribus. The $1 / E(T)$ phased withdrawal mimics the "default" pattern under U.S. tax law. It appeals to low and moderate levels of risk aversion.

Sharpe et al. $^{24}$ examine some rules of thumb from financial advisors to see if they are consistent ("efficient") with expected utility maximisation (the investor's "revealed utility"). The canonical setting assumes: (1) additively separable utility functions; (2) that spending preferences take into account both mortality estimates and the retiree's attitudes concerning spending relative to beneficiaries; and (3) that the amounts to be spent under the plan will go either to the retiree or to beneficiaries. They also assume that no annuities have been purchased. The main message is that retirees interested in fixed retirement spending should invest in the risk-free asset. Anyone who chooses to invest in the market should be prepared for more volatile spending. The results from Sharpe et al. $^{25}$ suggest a reliance on "lockbox" spending strategies. A given retirement strategy could be inefficient and could entail multiple spending levels for a given market return.

Ameriks et al. ${ }^{26}$ focus on the match between resources and spending needs, which leads to precautionary savings for long-term care and bequest motives. Hence, they value non-standard annuities (contingent annuities), useful for middle-class retirees. The contingent expenses make traditional annuities "risky assets" for annuitants facing health shocks. The demand of various financial products varies as a function of the strength of the precautionary motive and the bequest motive. Because annuitants are reluctant to exchange a large lump sum for future promises to pay, some

\footnotetext{
${ }^{23}$ Horneff et al. (2006).

${ }^{24}$ Sharpe et al. (2007).

25 Ibid.

${ }^{26}$ Ameriks et al. (2007).
} 
immediate annuity products are now sold with "refund features" or other options. Ameriks et al. (2007) outline and evaluate three better-targeted annuities: (1) a reversible annuity until long-term care is needed, (2) a longevity insurance contract and (3) a life-annuity combined with extra payments triggered by long-term care needs.

Since voluntary annuitization remains extremely low, Webb et al. ${ }^{27}$ propose an innovative annuity product - the Advanced Life Deferred Annuity (ALDA) - which provides relatively high longevity insurance at a relatively low cost. It is an annuity that would be purchased at retirement, or even earlier, but the associated payments would not start until some advanced age (e.g., 75, 85 or 90). The long deferral period would result in a very inexpensive product; for example, Webb et al. ${ }^{28}$ calculate that the cost of no more than 15 per cent of the wealth at age 60 could purchase an ALDA with payments commencing at age 85 . The life annuity and long-term care insurance markets naturally attract opposing risk groups. Life annuities appeal to those with higher than average life expectancies since long-term care insurance demand is led by those who believe they have a greater need for coverage. A combination of both annuity and long-term care insurance allows the former to be cheaper and to expand coverage to a wider public with the latter.

\section{Regulatory constraints and opportunities}

Financial regulation, like overall economic regulation, rests on the market failure perspective. ${ }^{29}$ Efficient results are expected from competitive markets in the absence of natural monopolies, externalities, public goods and/or asymmetric information.

In the pensions and insurance arena free riding, moral hazard and adverse selection could arise; fraud and malfeasance could also occur given asymmetric information. Because of the former, some markets have disappeared (or never developed). Since covered contingencies do not exist, regulation is key to developing markets as well as to protecting the consumer of financial services. Financial education has a "public good" element and avoiding financial crisis can prevent deleterious systemic effects. ${ }^{30}$

Annuity regulation is essential to ensure the integrity of the system. It comprises the prudential regulation of insurance companies, the business conduct regulation of insurance companies and annuity regulation within the overall pension system. Financial regulation is designed to protect consumers in areas that are too complex for them to protect themselves. ${ }^{31}$

The main risks in annuities are related to mortality and interest rate assumption and credit and other broader systemic risks. The risks for the provider are the degree to which returns on the portfolio match the promised income stream and the quality of the mortality assumptions. The conventional annuity in English-speaking countries is

\footnotetext{
${ }^{27}$ Webb et al. (2007).

28 Ibid.

29 Stiglitz (1994).

${ }^{30}$ Davis (2001).

${ }^{31}$ Davis (2002).
} 
the nominal-fixed contract, but real annuities are common in inflationary contexts. Unlike traditional policies, where mainly bonds are used to back liabilities, variable policies imply active investment in equities, real estate and international investments, which are expected to keep pace with inflation. The related assets may often be held in the form of mutual funds. Risky portfolios are transformed into risk-free outflows by means of risk reduction and risk-shifting approaches. In terms of risk reduction, insurers employ investment diversification, including foreign assets, derivatives or hedging (if allowed), the sharing of risk across product lines whose risks are orthogonal - such as annuities and life or long-term care insurance - and use cash inflows to provide liquidity. In connection with risk shifting, insurers employ reinsurance, annuity guarantee pools and risk sharing between cohorts of different products. ${ }^{32}$

Prudential regulation of insurance companies with regard to annuities is directed, in particular, at solvency and assets regulation. The main focus of solvency regulation is on reserves and investments held against the capital base. Assets held as reserves are constrained by the risk characteristic of the liabilities. The prudential regulation of reserves requires a focus on prospective liabilities based on existing contracts. The main issues are the mortality assumptions, the discount rate and future expenses to cover the expected full administration costs. Capital adequacy and reserving requirements impose a floor on the policy prices, given a desired return on capital. Since solvency requirements are now risk-based, they impact on the supply of more complex annuity products. On the demand side, the lack of comprehension of products complicates the consumers' choices. ${ }^{33}$

To address the adverse selection in the annuity markets, annuity purchases could be made mandatory, or could be forcing the decision to choose a lump-sum payment instead of an annuity to be made before retirement. If the funds are supplemental, it is reasonable to leave the choices more open. In some countries, programmed withdrawal is the only possibility since annuity markets are undeveloped.

Tax provisions are a key element when designing incentives in one direction or another. The equivalent tax treatment of various forms of retirement arrangements could be defended as the neutrality of the tax system. Some limits could be set, like a maximum lump sum after a minimum replacement rate is achieved with annuitized pensions. ${ }^{34}$

On product design, the basic choice in terms of regulation is between strict controls of products - maintaining a standard design and even price controls - and allowing for free innovation - along with information disclosed to consumers.

\section{Proposals and simulations}

Since the publication of a seminal World Bank document, ${ }^{35}$ the concept of the "multipillar" model has been introduced. The accumulation phase of pensions

\footnotetext{
${ }^{32}$ Ibid.

${ }^{33}$ Stewart (2007).

${ }^{34}$ Davis (2001).

${ }^{35}$ World Bank (1994).
} 
includes three "Pillars": (1) a flat pay-as-you-go redistributive pension, (2) a private fully funded personal savings account and (3) private voluntary savings. Gill et al. ${ }^{36}$ review that study in light of the experience of various reforms in emerging countries. The pillar analogy has been a good communication device and it is linked to social security goals: redistribution, saving and insurance. For this discussion, Barr $^{37}$ and Orszag and Stiglitz ${ }^{38}$ give a critical view. ${ }^{39}$

The previous discussion on ageing, the demand side, the supply side and regulation yields some lessons for the pensions' decumulation phase:

(1) Pensioners face new risks as they will have access to an important mass of financial resources and will be subject to opportunities and perils.

(2) Flexibility is necessary. It seems to be a transaction, a precautionary and a speculative demand motive in the mind of retirees: the first has to do with a flow of regular expenses, the second with likely health shocks and the third with the temptation to exchange higher returns by/for increased risk. Additionally, solidarity between generations implies a demand for legacies.

(3) New products offered by the industry could satisfy consumers, but at the risk of being too expensive and of showing adverse selection if purchased voluntarily.

(4) Regulators are interested in a safe and sound environment to protect consumers. Standardised products are easier to regulate and monitor than case-by-case ones. Simple packages are preferable to complex ones. Taxes matter.

(5) International organisations seek financial stability; they demand instruments and regulations, which can prevent a financial crisis or minimise its effects.

(6) Politicians seek the less disturbing and more rewarding solutions.

(7) Insurers are trying to build up a more profitable business, but they are threatened by competition and the narrowness of the annuity markets.

Bearing in mind these points, how could the insurance industry cope with the ageing phenomenon? Based on the experience of the pension industry, some useful analogies can be drawn to extend the business of insurers. Based on these assumptions, a proposal can be imagined which consists of a "Multi-tier Insurance Package for the Pensioners' Saving Decumulation Phase” (MIP). The MIP addresses the consumers' desires, is flexible enough, appeals to regulators and international organisations, benefits politicians engaged with reforms and is a promising business for the providers that can structure and sell the products.

The First Tier of the MIP is the voluntary "Allowed Lump-Sum Decumulation". A part of the gross savings from the accumulation phase can be withdrawn by the future pensioner at the legal age of retirement, provided a certain Targeted Replacement Rate is notionally achieved.

The Second Tier of the MIP is the voluntary "Lockbox Phased Withdrawal". Every "lockbox" isolates amounts devoted to satisfying different needs in the next tier and is

\footnotetext{
${ }^{36}$ Gill et al. (2004).

${ }^{37}$ Barr (2002).

38 Orszag and Stiglitz (1999).

${ }^{39}$ For an updated description of the reforms in emerging economies, see www.aiosfp.org and www.fiap.cl.
} 
subject to different constraints either to increase or limit the variability of the returns (lower for the consumption lockbox). The long-term care lockbox depends on the institutional environment: if there is a substitute (such as Medicare in the United States), running more risks is possible and so on.

The Third Tier of the MIP is the "Mandatory Annuitization through 'Annuiplus' Purchase". Annuiplus is either a bundle of Annuity plus Death Insurance ("Annuiquest", addressing bequest motive), or Annuity plus Long-Term Care Insurance ("Annuicare", addressing long-term care motive), or Annuity plus Long-Term Care plus Death Insurance ("Annuicarequest", addressing both motives).

Table 4 Multi-tier insurance package for the pensioners' saving decumulation phase (MIP)

\begin{tabular}{|c|c|c|c|}
\hline & First Tier & Second Tier & Third Tier \\
\hline Name & $\begin{array}{l}\text { Allowed lump-sum } \\
\text { decumulation }\end{array}$ & $\begin{array}{l}\text { Lockbox phased } \\
\text { withdrawal }\end{array}$ & $\begin{array}{l}\text { Mandatory annuitization by } \\
\text { "annuiplus" purchase }\end{array}$ \\
\hline Character & Voluntary & Voluntary & $\begin{array}{l}\text { Mandatory } \\
\text { (deferment is voluntary, } \\
\text { immediate purchase is } \\
\text { mandatory if Second Tier is } \\
\text { step) }\end{array}$ \\
\hline Resources & Gross savings & $\begin{array}{l}\text { Net savings } \\
\text { (gross savings-lump } \\
\text { sum) }\end{array}$ & $\begin{array}{l}\text { Lockboxes } \\
(>,<, \text { or }=\text { net savings of the } \\
\text { Second Tier })\end{array}$ \\
\hline Output & Lump sum & $\begin{array}{l}\text { Phased withdrawal } \\
\text { (locked in } \\
\text { "boxes"-subaccounts) }\end{array}$ & $\begin{array}{l}\text { Annuiquest or } \\
\text { Annuicare or } \\
\text { Annuicarequest or } \\
\text { a classic Annuity }\end{array}$ \\
\hline Rationale & $\begin{array}{l}\text { Free disposal of an } \\
\text { amount of money } \\
\text { (a stated percentage or } \\
\text { amount from gross } \\
\text { savings, provided a } \\
\text { notionally targeted } \\
\text { replacement rate is } \\
\text { achieved) }\end{array}$ & $\begin{array}{l}\text { To increase the } \\
\text { resources in the post- } \\
\text { accumulation phase and } \\
\text { to preserve liquidity. } \\
\text { Subject to investment } \\
\text { risk. }\end{array}$ & $\begin{array}{l}\text { To smooth consumption } \\
\text { avoiding moral hazard (annuity } \\
\text { part). } \\
\text { To leave a bequest (death } \\
\text { insurance part). } \\
\text { To afford high long-term care } \\
\text { expenses. } \\
\text { Bundles are thought to match } \\
\text { insurers' risk, they are } \\
\text { mandatory to allow for scale } \\
\text { and scope economies and to } \\
\text { reduce the overall risk the } \\
\text { sector faces and they are } \\
\text { indexed to protect pensioners. }\end{array}$ \\
\hline $\begin{array}{l}\text { Proposed } \\
\text { Tax } \\
\text { Treatment }\end{array}$ & As income of the period & $\begin{array}{l}\text { As income of the period } \\
\text { for increases in the value } \\
\text { of the shares in each } \\
\text { period } \\
\text { (due to capital gains, } \\
\text { interests or dividends, } \\
\text { net of expenses and } \\
\text { fees). }\end{array}$ & $\begin{array}{l}\text { No taxation for the death and } \\
\text { care insurance payments. } \\
\text { As income of the period for } \\
\text { annuities payments }\end{array}$ \\
\hline
\end{tabular}

Source: Own elaboration. 
The deferment period of the Annuiplus is subject to three particular conditions: if Second Tier is not chosen, then the purchase is immediate, otherwise it is deferred; the maximum deferment period has to be related to each country's life expectancy; and considering the timing of financial markets, waivers could be permitted to avoid annuitization during adverse periods.

The Annuiplus products are indexed. In the case of no bequest and long-term care motive, the retiree can buy a standard indexed annuity. Some redistribution features could be introduced by means of unisex mortality tables, differentiated mortality tables for race and a different tax treatment than that proposed here. The proposal is summarised in Table 4.

Some simulations were made to estimate possible results. Suppose a male aged 65 has gross savings of U.S. $\$ 150,000$. He can choose between two bundles: the first includes a lump sum of U.S.\$15,000, a U.S.\$10,000 "bequest" via a death insurance policy and an Immediate Annuity of U.S.\$9,562.30 per year. The second alternative includes the same lump sum and "bequest", a 5-year Deferred Annuity of U.S.\$9,562.30 per year and a Phased Withdrawal with the balance for the next 5 years. Assume the load on the pure premium for the death insurance is 5 per cent and that the load factor for annuities is a weighted average comprising 10 per cent of voluntary annuitant population, 90 per cent of general population and life expectancy averaged on halves (males and females). Also suppose that efficiency gains, because of economies of scale and scope, reduce the load factor by 3 per cent. Simulations are done with the SSA mortality table (and MWR) for the United States and assume a benchmark discount rate of 4 per cent. The premium calculations can be seen in Table 5. See Figures 1 and 2 for different discount rates and Figures 3 and 4 for different ages of purchase.

Table 5 MIP in action: calculations for U.S. mortality and MWR values, corrected by efficiency gains

\begin{tabular}{lrlr}
\hline $\begin{array}{l}\text { Bundle } \\
\text { (Lump Sum + Immediate Annuiquest since 65) }\end{array}$ & $\begin{array}{l}\text { Bundle } \\
\text { (Lump Sum + Deferred Annuiquest since } 70)\end{array}$ \\
\hline Component & U.S. \$ & Component & U.S. \$ \\
\hline Lump sum & 15,000 & Lump sum & 15,000 \\
"Bequest" & 5,657 & "Bequest" & 5,657 \\
Immediate annuity & 129,343 & Immediate annuity & 82,066 \\
Phased withdrawal & 0 & Phased withdrawal & 47,278 \\
& 150,000 & Total & 150,000
\end{tabular}

Weighted MWR $=(0.9 \times((0.5 \times 0.816)+(0.5 \times 0.829)))+(0.1 \times((0.5 \times 0.916)+(0.5 \times 0.893)))=0.8307$.

Weighted load $(\mathrm{wl})=1 /$ weighted $\mathrm{MWR}=1.203804$.

Weighted load adjusted (wla) $=0.97 \mathrm{wl}$ due to gains in efficiency and economies of scale and scope $=$ 1.1676899 .

Assumed: annuitant population $=0.1$ total population, males $=0.5$ total population. Using public bond rate or yield curve.

Source: Own elaboration; MWR from Mackenzie (2002). Social Security Administration, online Period Life Table (Updated 09/07/07). 
The Geneva Papers on Risk and Insurance - Issues and Practice

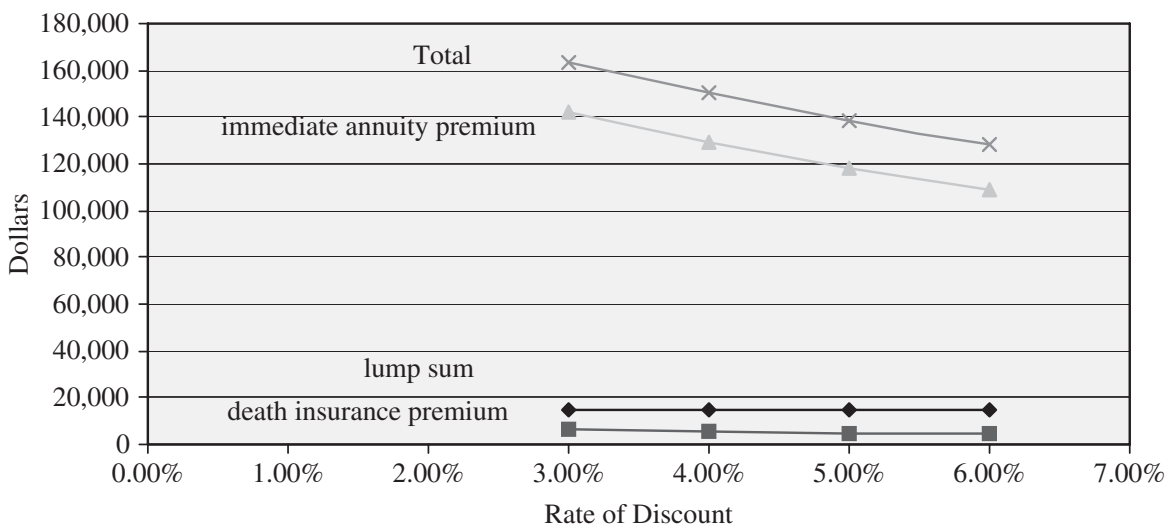

Figure 1. Premium of an Annuiplus (immediate).

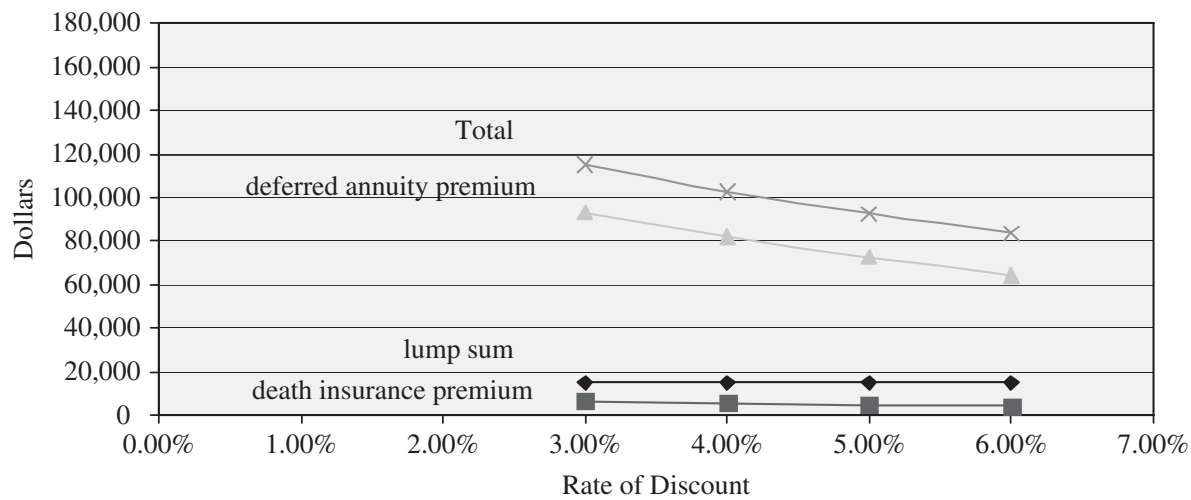

Figure 2. Premium of an Annuiplus (deferred).

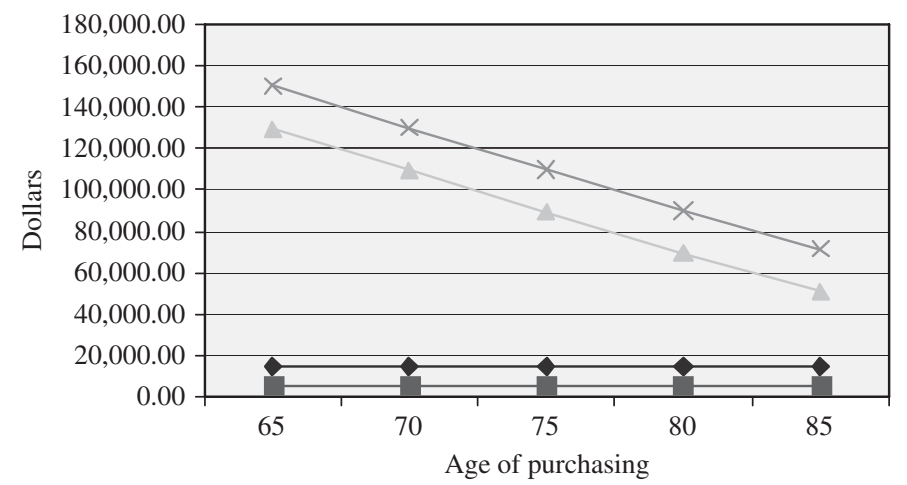

$\multimap$ lump sum $\multimap-$ death insurance policy $\longrightarrow$ immediate annuiplus $\leftarrow$ Total

Figure 3. Premium of an Annuiplus (immediate, 4 per cent rate of discount). 


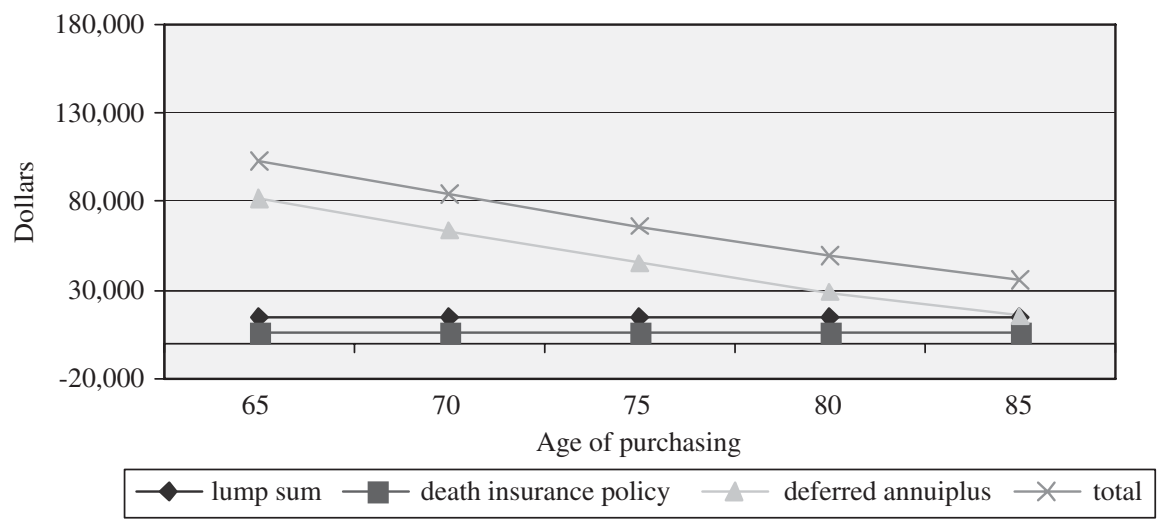

Figure 4. Premium of an Annuiplus (deferred 5 years, 4 per cent rate of discount).

\section{Conclusions}

The road we followed suggests that the "mini" scenario (the insurance industry's "reactive" response to ageing) is the most likely given demand tendencies, competition and pressures from regulators. Moreover, insurers do not appear to be on the "radar" of politicians and international organisations. The combined results produce little business and low margins. One way to increase business is to raise the profile of the industry and to "sell" its products more widely (not thinking only of the clients).

In our view, if the diagnosis is shared, some shock is necessary (a "proactive" answer) to capture the attention of politicians, international organisations, regulators and clients in this order. One possible "mega" scenario was outlined here, where reforms are suggested to enlarge the market by means of a "multi-tier" insurance scheme that could deal with the pension decumulation phase. "Multi-tier" could cover the needs of the demand side. Annuitization at any flexible time is mandatory to lower adverse selection (and premiums). Politicians could offer some redistribution managing mortality tables and timing of the tiers. Regulators can standardise products, which, in turn, tend to lower costs and can ease reserve requirements since opposing risks are matched.

The premiums calculated in the simulations are conservative: the industry can capitalise on the growth of the market to achieve greater economies of scale and scope. It is also true that the very participants in the industry have considerations on becoming more involved in the business of annuities (since mortality risk appears uncontrolled). Nevertheless, annuity contracts continue to be unique products to cover the longevity risk in a way that no other financial product does.

\section{References}

Alier, M. and Vittas, D. (2001) 'Personal pension plans and stock market volatility', in R. Holzman and J. Stiglitz (eds) New Ideas about Old Age Security, Washington, DC: The World Bank, pp. 391-423.

Ameriks, J. (2003) How do retirees go from stock to flow? Pension Research Council working paper 2003-18, The Wharton School, Philadelphia.

Ameriks, J., Caplin, A., Laufer, S. and Van Nieuwerburgh, S. (2007) Annuity valuation, long-term care and bequest motives, Pension Research Council working paper 2007-20, The Wharton School, Philadelphia. 
An Bord Pinsean (The Pensions Board) (2004) A Brief Guide to Annuities, Dublin: The Pensions Board.

Antolin, P. (2007) Longevity risk and private pensions, working paper on Insurance and Private Pensions No. 3, Paris, OECD.

Barr, N. (2002) The Pension Puzzle. Prerequisites and Policy Choices in Pension Design, Washington, DC: International Monetary Fund.

Batini, N., Callen, T. and McKibbin, W. (2006) The global impact of demographic change, working paper 06/9, International Monetary Fund, Washington, DC.

Brown, J. and Poterba, J. (2004) Household demand for variable annuities, Center for Retirement Research working paper 2004-08, Boston College.

Davis, E.P. (2001) Portfolio regulation of life insurance companies and pension funds, discussion paper PI-0101, The Pensions Institute, OECD, Paris.

Davis, E.P. (2002) Issues in the regulation of annuities markets, working paper 26/02, Center for Research on Pensions and Welfare Economics, Turin.

Dus, I., Maurer, R. and Mitchell, O. (2003) Betting on death and capital markets in retirement: A shortfall risk analysis of life annuities versus phased withdrawal plans, working paper 2003-063, University of Michigan Retirement Research Center.

Gill, I., Packard, T. and Yermo, J. (2004) Keeping the Promise of Old Age Income Security in Latin America. A Regional Study of Social Security Reform, Washington, DC: The World Bank.

Horneff, W., Maurer, R., Mitchell, O. and Dus, I. (2006) Optimizing the retirement portfolio: Asset allocation, annuitization and risk aversion, Pension Research Council working paper 2006-10, The Wharton School, Philadelphia.

Jousten, A. (2007) Public pension reform: A primer, working paper 07-28, International Monetary Fund, Washington DC.

Mackenzie, G. (2002) The role of private sector annuities markets in an individual accounts reform of a public pension plan, working paper 02/161, International Monetary Fund, Washington, DC.

Mackenzie, G. and Schager, A. (2004) Can the private annuity market provide secure retirement income? working paper 04/230, International Monetary Fund, Washington, DC.

OECD (2007a) 'Private pensions: A growing role', in OECD (ed) Pensions at a Glance: Public Policies Across OECD Countries, Paris: OECD.

OECD (2007b) Pension Markets in Focus, Paris: OECD, Issue 4 (November).

Orszag, P. and Stiglitz, J. (1999) Rethinking pension reform: Ten myths about social security systems, Conference on "New Ideas on Old Age Security", The World Bank, Washington, DC.

Panis, C. (2003) Annuities and retirement well-being, Pension Research Council working paper 2003-19, The Wharton School, Philadelphia.

Sharpe, W., Scott, J. and Watson, J. (2007) Efficient retirement financial strategies, Pension Research Council working paper 2007-19, The Wharton School, Philadelphia.

Stewart, F. (2007) Policy issues for developing annuities markets, OECD working paper on Insurance and Private Pensions No. 2, OECD, Paris.

Stiglitz, J. (1994) The role of the state in financial markets, Proceedings of the World Bank Annual Conference on Development Economics, 1993, The World Bank, Washington, DC.

Webb, A., Gong, G. and Sun, W. (2007) An annuity that people might actually buy, Brief No. 7-10, Center for Retirement Research, Boston College.

Whitehouse, E. (2007) Life-expectancy risk and pensions: Who bears the burden?, Social, Employment and Migration working paper No. 60, OECD, Paris.

World Bank (1994) Averting the Old Age Crisis: Policies to Protect the Old and Promote Growth, (World Bank Policy Research Report), New York: Oxford University Press.

\section{About the Author}

Gustavo Ferro holds a doctorate in Economics. He is a professor researcher at the Universidad Argentina de la Empresa (UADE) and CONICET in Buenos Aires, Argentina. 